\title{
Re-visiting the Quasi-Market in Employment Services: Australia's Job Network
}

\author{
Catherine McDonald and Greg Marston
}

\begin{abstract}
Australia's Job Network is an example of the quasi-market model applied to employment services. It has been in operation now for over ten years. This article explores its functioning predominantly in terms of public choice and agency theory which promotes the quasi-market model. It augments that analysis with the application of a normative framework asking if the Job Network promotes choice, voice and citizenship. Using evidence and data from different sources, it suggests that the Job Network, despite claims, largely fails to deliver in the manner suggested by the theoretical accounts.
\end{abstract}

\section{Introduction}

In 2006, Stephen Bubb, the chief executive of the British Association of Chief Executives of Voluntary Organisations, campaigned vigorously for adoption in that country of the Australian model of employment service provision - known as the Job Network (Davies 2008: 140). Along with the Netherlands, Australia has been identified by the Organisation of Economic Cooperation and Development (OECD) as a "world leader" in the introduction of quasi-markets in labour market services (Struyven 2004). In the light of international interest, we examine whether the Australian Job Network quasi-market, now in operation for over ten years, does provide "superior" service.

We evaluate the Job Network through three types of criteria drawn from quasi-market theory about what promotes a properly functioning quasi-market. First, we assess whether the Job Network operates in the manner suggested by technical criteria embedded in quasi-market theoretical accounts. We do this by sketching the ideal model of a quasimarket and comparing that to the functioning of the mature Job Network. Second, drawing on a range of extant commentary and evidence, we apply what we call "relationship" criteria as pertaining to the relationship between purchaser and provider, similarly drawn from theory. We conclude with a normative principle which policy analysts would normally apply to any evaluation of a policy. This final step ultimately informs our assessment of the impact of the Job Network on Australian government and Australian democracy. Our conclusion both asks and begins to answer the question: Is it the model, or is it the mode of application which promote the outcomes we describe? 


\section{Quasi-Markets}

Typically, quasi-markets are held out by supporters of public choice theory as a superior response to what they characterise as a flawed traditional belief in public administration - that governments provide services in response to, and as a safeguard from, market failure. In that traditional formulation, governments were understood to serve as a corrective when inevitable externalities undermine the virtues of market exchanges (Lowery 1998). Using a similar logic, public choice theory is a theory about nonmarket (state) failure. As Lowery (1998: 138) argues, there has been a generation of public administration scholars who have noted the many ways that "democratic and bureaucratic institutions imperfectly aggregate, represent and implement consumers' preferences". To support his claim, he cites such seminal authors as Buchanan and Tulloch (1962), Buchanan and Tollsen (1972), Niskanen (1971), Olson (1965) and Williamson (1985).

From a public choice theory perspective, the rent seeking behaviour of bureaucrats promotes uncontrollable growth in public expenditure and public employment, creating large fiscal deficits and general public dissatisfaction with government services. Schwartz (1994: 55) identifies four issues of concern: public sector agencies are subject to capture by their clients whose interests are rarely isomorphic with the general public; public sector bureaucracies tend towards "self capture", often resulting in non-rational decision making; despite client capture, state bureaucracies are often non-responsive to client needs and under or over-provide inefficiently; and politicians often pressure state bureaucracies into providing inefficient and/or non cost-effective extensions of services or interfere with the ability of bureaucracies to pursue their mission.

In Olson's (1965) terms, these issues arise when there are asymmetries in the interests and ability of groups to organise, and to differences in their ability to use exit and voice to influence organisations. Small groups with narrow and well-defined interests are better at claiming resources than large, diffuse, poorly organised groups. These asymmetries lead to "capture" and produce "rents" as benefits which accrue to some that exceed those that would apply in a free market. Rent seekers often use voice to generate political pressure on governments, which then respond to their claims using taxpayers' money. And taxpayers - a large and diffuse group if ever there was one - cannot exercise voice nearly as effectively, and at the same time they cannot exit from taxpaying. Furthermore, as Williamson (1985) argues, the mode of public service provision reinforces tendencies towards rent seeking through the addition of the moral hazard problem: that is, agents will only pursue principals' interests when those interests coincide with their own. If the general public or any (large and diffuse) sub section of the general public are the principals, albeit with their voice mediated though politicians, their interests will be poorly attended to by bureaucracies and bureaucrats. 
From a public choice perspective, the role of values or ideology is irrelevant. If anything, values and ideologies serve to mask rational action. Values such as commitment to social justice, commitment to the notion of professionalism and sets of professional ethics, or commitment to the ideals of an impartial public service - all of these have little place in public choice theory. Public choice prescriptions for government seek to limit the power and discretion of public servants by, for example, exposing public functions to competitive tendering - while similarly seeking to constrain the power of politicians. Another tactic is the relocation of government functions outside of government (contracting out) and by the creation of quasi-markets. By such processes, public choice-inspired reforms have influenced the redesign of state organisations: for example, corporatisation, the establishment of separate business units within organisations, and the introduction of internal markets.

Agency theory (Grossman \& Hart 1983) is a particularly influential strand of public choice theory. It introduces many of the principles that now characterise public service delivery: for example, the concepts of principals and agents. Agency theory examines the relationship between principals and agents. A principal is one who sets the task; an agent is one who implements it. The central problem for principals is how to control agents, particularly opportunistic rent seeking agents. According to principal-agent theory, principals have two broad strategies for keeping agents in line. First, there are structural solutions: increasing the information available to principals through performance indicators and increased financial accountability. Second, there are contractual solutions: the quasi-market, opening up internal operations of state agencies to various forms of tender, thereby creating competition or increasing contestability through the use of contracts. Contracts are the key medium negotiating the relationship between principals and agents. Relationships constructed within a contract are subject to contract law, and can be enforced though legal action. Contracting, by its specified and regulated nature, is thought to overcome the risks of rent seeking inherent in principal-agent relationships. In this way, accountability is maximised and effects of rent seeking behaviour are minimised.

From a theoretical perspective, there are four technical or instrumental requirements if a quasi-market for publicly funded services is to function (Struyven \& Steurs 2005; LeGrand \& Bartlet 1993). These are: that there is a competitive market structure; that all of the relevant information is available; that there are minimal transaction costs; and that there are the right incentives.

A decade ago, Hardy and Wistow (1998), two of the main British scholars of the application of quasi-markets to social care, wrote what was in effect a review article in which. among other things, they outlined four characteristics of a "mature purchasing framework". The characteristics are: long-term relationships between purchasers and providers; mutual trust; a 
mutual understanding of the needs and intentions of purchasers, together with the motivations and vulnerabilities of the providers; and sufficient stability in purchasing patterns.

Together, these requirements and characteristics provide a useful template to assess the functioning of the Job Network - a quasi-market exemplar. They are set out in Table 1.

Table 1

Template to Assess the Functioning of the Job Network

\begin{tabular}{|l|l|}
\hline Category of Criteria & \multicolumn{1}{c|}{ Criteria } \\
\hline Technical criteria & $\begin{array}{l}\text { Competitive market structure } \\
\text { Correct incentives } \\
\text { Minimal transaction costs } \\
\text { Relevant information }\end{array}$ \\
\hline Relationship criteria & $\begin{array}{l}\text { Long term relationships between purchaser/s } \\
\text { and providers } \\
\text { Mutual trust }\end{array}$ \\
\hline
\end{tabular}

\section{The Job Network}

In establishing the Job Network in 1998, the Australian Government adopted what the OECD (2001) considered to be one of the most radical experiments in employment services to the unemployed. Replacing the long-standing government operated labour exchange, the Australian government created an integrated quasi-market of employment services linking the purchaser (the Department of Education, Employment and Workplace Relations ${ }^{1}$ - DEEWR) with two categories of provider. One of these is Centrelink, the primary government run income support agency, and the other is the Job Network, currently a system of over one hundred for-profit and non-profit service agencies operating in over two thousand different sites across the nation. Australia's Productivity Commission (2002) has called this system "one of the first comprehensive attempts internationally to apply market mechanisms to the provision of subsidised employment services".

Job Network agencies work within contractual arrangements entered into with DEEWR. Since 1998, there have been three rounds of tenders, resulting in what is known as "employment service contracts" (ESC 1, 2 \& 3). Initially tendering decisions were based on price and quality; but in the latest round, quality was the variable of choice. Over time, the number of organisations in the Job Network has shrunk from 306 to 103, about half of 
which are non-profit and half private for-profit (Thomas 2007).

Job Network members provide different types of employment services to the unemployed, depending on their assessed degree of employability. The most "employable" receive basic labour exchange services provided via an integrated information system accessed through terminals in each Job Network outlet, as well as a number of other organisations outside the Job Network. After three months, unemployed people are assigned to "intensive support". These people come with "job seeker accounts" which a Job Network provider can access to cover some of the costs of job search activity. Providers are, at this stage, also eligible for outcome payments. As the length of time a person is unemployed increases, he or she is eligible for more support and assistance. People who are assessed to be at high risk of continued unemployment or who have been unemployed for over twelve months are offered "intensive support customised assistance" for six months, which consists of such interventions as training, work experience, referral to specialist services to resolve personal issues, work experience, and post-placement support. While providers have considerable discretion over what they undertake, by ESC 3, minimum service provision specifications were imposed. If a person presents with such complex needs that the Job Network cannot address, he or she is referred to the "personal support program".

When a person presents at Centrelink to register for income security, the Centrelink staff undertake an assessment of the level of risk of remaining unemployed. They then prepare a "preparing for work agreement" which lists rights and obligations. The unemployed person is asked to choose which provider they wish to attend and, if they do not choose within seven days, Centrelink chooses for them depending on Network capacity. Centrelink brokers the first contact. Individual income security payments commence only when the person makes contact with their nominated Job Network provider, and under ESC 3, the person is required to register with one provider for that period of unemployment. For those whose unemployment persists for two years, or who have not gained employment six months after completing "intensive support customised assistance" are required to undertake a second six months of "intensive support". If that fails to help them into employment, they will be required to undertake a mutual obligation activity - an activity which may include a form of community work (ANAO 2006). Engagement with the Job Network, a condition of benefit receipt, is compulsory, and failure to participate results in financial penalties in the form of benefit reduction or non-payment.

\section{Is the Job Network a Quasi-Market?}

The Job Network was certainly designed as such. Responding to the perceived inflexibility of the previous state-run labour exchange, it was, through the introduction of a purchaser-provider split and the introduction 
of competition between providers, designed to improve service quality, to target assistance more effectively, to address the structural weaknesses of government provision, and to achieve economic efficiencies (Vanstone 1996). Nevertheless, ten years on there are doubts that the Job Network functions well as a quasi-market, largely due to the incremental introduction of various processes by the purchaser, DEEWR, over the decade of operation. It is, as the OECD acknowledges, an evolving system, adapting and adjusting continuously (Struyven 2004). Of interest here is whether the Network meets the technical criteria of a functioning quasimarket.

The first to be considered is whether the market structure is competitive, and the answer is that it is only partially so. The Job Network is a monopsony: that is, rather than there being a range of purchasers (as one would expect in a market), there is only one - and it is one which is organised in a "strongly centralist/hierarchical way" (Struyven \& Steers 2005: 215). This feature of the Job Network constrains competition in that the purchasing department deems quality to be the key characteristic for awarding contracts. "Quality" is measured by "success" which itself is determined by the purchaser according to a complex assessment system in which previous engagement with the client group and the contract system is the only way of achieving a rating. Two features are worth noting here: the actual numbers of providers has shrunk considerably over the three contract periods; and new entrants to the Network have also declined. Under ESC 2, one in six providers was new. Under ESC 3, that ratio has dropped to one in fourteen (Struyven \& Steers 2005: 216). Further, this shrinkage of the capacity of the Job Network to be appropriately competitive is exaggerated significantly in rural areas where there is not enough demand to support more than one provider.

Second, the transaction costs of the Job Network are high - both for the purchaser and the provider. Transaction costs accrue through engaging in the tendering process, through implementing the programme, and in monitoring compliance (Williamson 1985). These high costs speak to a dilemma in the tendering model. On the one hand, one of the goals is to produce better and cheaper services, a goal which can be achieved through the introduction of competition. On the other, the tendering rounds themselves generate high transaction costs. While it is possible to reduce transaction costs by moving to more stable purchaser and provider relations, this works against the original intentions behind market-based contracted service (Bredgaard \& Larsen 2006). Murray (2006) has calculated the costs to DEEWR in administering the Job Network at A $\$ 252$ million, which is 15.2 percent of the total $\mathrm{A} \$ 1,658$ million spent on the programme. He had also calculated that 1,200 departmental staff supervise 1.100 sites being 1.1 staff members per site, or 11.6 per provider organisation.

Overall, administrative and compliance costs to providers are very high (Thompson 2008; Thomas 2007; Webster 1998). Under ESC 3, DEEWR 
has escalated its administrative oversight of the Job Network, particularly in relation to the "job seeker accounts", monitoring how providers spend them (ANAO 2006). This has also boosted transaction costs. Aggregating the dollar amounts, Murray (2006: 19) notes that for overall Centacare ${ }^{2}$ Employment sites, the organisation was open for scrutiny for every A $\$ 500$ claimed under ESC 3 compared with every A\$900 in ESC2:

Indeed, since early June 2006 [to the time of publication several months later], Centacare Employment has received requests to justify 113 claims for payment at a rate of over 5 or 6 a week. A quarter of these claims were for under $\$ 200$ with half of those under $\$ 100$. The amounts of money involved vary from $\$ 17.93$ to $\$ 4,400-$ some resulted in partial recovery is as low as $\$ 9.81$.

Third, there are concerns about the incentive structure of the Job Network. The outcomes-based payments structure adopted by the Job Network was supposed to increase cost-effectiveness and to promote the provision of assistance to high need people through larger payments. Instead, it has provoked practices colloquially known as "parking", and its converse "cherry picking" or "creaming", in which hard-to-place people are offered minimal or no service by some providers, with the money which should have been spent being re-directed to others more likely to generate an outcome payment (Thomas 2007; Struyven \& Steurs 2005; Productivity Commission 2002; Considine 2001). As Thomas (2007: 18) notes: "Because Job Network providers received an upfront commencement payment irrespective of employment outcome, so long as they did not spend too much on service provision for job seekers in Intensive Assistance, their profitability would be assured".

Ironically, DEEWR's attempts to overcome "parking" through increased monitoring and regulation have contributed significantly to the increased transaction costs on both sides of the contract under ESC 3 (Thomas 2007). Further, "creaming" and "parking" are almost unavoidable in a framework of market-economic logic as employment outcomes are uncertain, with many job seekers presenting with complex problems requiring long-term and costly interventions.

Fourth, access to relevant information is limited in the Job Network in a number of ways. The users - unemployed people - lack sufficient information to make choices (to the limited extent they can) about which provider they wish to join, a characteristic known technically as "quasimarket failure by preference error" (Lowery 1998). Providers' knowledge about the market is constrained by organisational behaviour which promotes secretiveness, particularly in the periods of contract negotiations, bolstered by commercial-in-confidence provisions built into the Job Network. The overall lack of transparency has been consistently noted by third parties (OECD 2005; Eardley 2003; Nevile \& Nevile 2000; Cowling 
\& Mitchell 2003). While DEEWR has extensive knowledge about the functioning of provider agencies through its all-embracing monitoring system, the same information, or level of knowledge, is not available to the providers. Further, the so called "star rating model" - a set of weighted performance indicators used as the basis for results-based funding - is opaque to many in the Network. As Struyven and Steurs (2005: 217) state:

The main criticism of the instrument is the lack of openness regarding the way in which indicators are defined and measured. As a result, it is surrounded by an aura of distrust. Not surprisingly, therefore, the Productivity Commission argues in its evaluation report for total transparency of the star rating system.

While these concerns reflect doubts about the validity and reliability of the performance measures used, there is another issue embedded in the manner in which the measures are used by the purchaser. The star ratings are used to determine which providers get business and, consequently, which don't. On the basis of the distribution model used in the Job Network, the 30 percent of sites falling in the lowest three rankings (out of five with "one" being the best) are subject to scrutiny for loss of possible business. As already noted, there are now only 103 providers (as opposed to 306 in 1998) - so, the model inevitably means that those ranked in the lowest 30 percent are potentially subject to business reallocation. As David Thomson (2008), the Chief Executive Officer of Jobs Australia said in a recent submission to the Minister: "Consequently, even good providers are fearful of loosing business every six [now twelve] months".

On the four technical indicators listed in Table 1, any evaluation of the Job Network which suggests that it is a functioning quasi-market is not particularly convincing. While many of the criteria were met in the first round of the Job Network tendering process, the changes in subsequent rounds have changed elements of the model considerably. In many ways, the excessive compliance monitoring has introduced a significant degree of public re-regulation, resulting in public control and governance of the quasi-market. Some have gone so far as to argue that the Job Network does not operate through a tendering process, but instead is a preferred provider model (Sol \& Westerweld cited in Bredgaard \& Larsen 2006). The extent to which the Job Network promotes the relationship criteria for success is examined below by turning to what we know about the perspectives of case managers in provider organisations.

\section{Relationships in the Job Network}

Recalling quasi-market theory, trust and mutual understanding are nominated as essential features of a functioning quasi-market (Hardy \& Wistow 1998). Unfortunately, while there might be considerable mutual 
understanding of each other displayed by parties to the contracts, there is little trust on either side. Public choice theory itself suggests that trust is not something to be assumed, thus the use of contracts to minimise rent seeking. That said, DEEWR's level of mistrust of Job Network providers has led to the introduction of significant over-regulation and onerous and costly accountability requirements. The lack of trust and outright hostility this generates has also been noted by a number of commentators (Thompson 2008; Thomas 2007; Productivity Commission 2002). Elsewhere (McDonald \& Marston 2006), we provide substantial detail on this, quite toxic, relationship. Here, we draw on selected excerpts to make the point.

The data we use was drawn from an electronic survey of over 2000 case managers undertaken in 2005 by AC Nielsen on behalf of Jobs Australia. Part of the resultant data set was provided to us by Jobs Australia and, accordingly, we acknowledge the background intellectual property of the commissioning agents. The data set included two summary evaluative questions:

Q. 29 What do you think would be the most effective way to improve the current Job Network system?

Q. 30 Other comments you would like to make about the Job Network system?

The case managers wrote from one sentence to a small paragraph in response to each of these questions, resulting in 1,114 useable responses. Given the size and complexity of the data corpus, here we report material drawn from those excerpts that illuminate the relationships operative in and around the Job Network. We report themes that appeared with relatively high frequency in the data. Also, because of the size of the overall corpus, when coding the documents we only coded those responses which included some detail (i.e, two or more whole sentences). Thus, we are under-reporting the frequency by which these responses occurred in the entire data set. The following frequencies were observed:

Excessive administrative load: 329 responses

Attitudes towards the Job Network and DEEWR: 472 responses

Consistent themes were present in the data. The most consistent theme was significant unhappiness with the high (from their perspective, excessive) administrative load produced by the contract requirements, associated with a quantitative "outcomes" focus and the general contractual operations of the system. It would be almost impossible to overstate the centrality of this to the case managers' experience and the resulting degree of frustration and job dissatisfaction. A number of case managers 
claimed that they spent up to, and sometimes over, 50 percent of their time managing administrative requirements. Many others claimed that the original intent of the Job Network - to help people into work - was lost in the continual round of administrative demands. One, for example, wrote that: "Due to the huge amount of administrative tasks, Job Network Members are becoming similar to Centrelink in the function of managing unemployment rather than assisting with employment as intended".

Many respondents claimed that the administrative overload was severely hindering their capacity to work with people to the level of intensity required to actually assist them to overcome their barriers and get them into work. As one put it:

We need to take the emphasis off the demanding administrative expectations so that the Job Network can focus on the client and finding sustainable employment, rather than percentages, statistics, referrals and so forth to keep up with DEWR ${ }^{3}$ requirements to achieve a star rating to keep us in the game. The priority should be our clients, not whether we are doing enough to work a difficult-tointerpret system just to keep our jobs.

Very often, the concerns about the administrative load were couched in terms of the outcomes focus of the Job Network contracts. The problem is not with delivering employment outcomes per se, but the quantitative output approach to reaching and measuring defined targets. That focus puts significant pressure on case managers to the point that it is "not enjoyable to work here anymore". Thus, the processes used to achieve successful employment outcomes are lost in the drive to meet unrealistic performance targets. The demand for service, expressed in terms of large caseloads, works against the possibility of establishing ongoing rapport and tailored, individualised service delivery for clients. In essence, the competencies of traditional human service case management are not conducive to the output imperatives of a quasi-market. Accordingly, not surprisingly, a Dutch study (where employment services tendering has been in place for some time) found that for these reasons few of the former public sector employment employees sought work with the private providers (Visser \& Hemejick 1997). The examples used above were not isolated cases or exaggerated claims. They constituted the majority of responses.

The second significant factor revealed in case managers' responses to the two questions concerned problems in the relationships between the various parts of the system - all of which are shaped by principles drawn from public choice and agency theory. This has at least two components. One involves problems in the relationships between Job Network agencies as a function of the competitive nature of the contract rounds. Thus:

The essential problem is that the Job Network is NOT A NETWORK, but rather a large number of separate organisations 
who regard one another as competitors, and therefore, have no incentive to work as a network. The end result of this is not that competition encourages good performance, but rather, encourages cynical shortcuts of the System which does nothing to encourage the maintenance of a strong NETWORK that both employers and job seekers can identify with let alone have confidence in. Moving back towards a system which has more in common with the previous Commonwealth Employment Service would be more helpful.

The administrative load was regularly associated with escalating negative staff attitudes, such that, for example:

I feel this system at the moment is an absolute disaster and is burning out many staff. You will loose a lot of the long term staff. The system is causing irreversible damage to the minds of people working in it. It creates too much paper work and not enough personal help to clients. It has become a process line job. Job satisfaction in helping people is out the window now and as soon as I can get out I will. I personally know of the same attitude in others.

The case managers also indicated concern about their relationship with their "purchaser" - DEEWR. Many case managers reported that the goal posts seem to move on a daily basis, and they felt that DEEWR should be working with the Job Network agencies not "fighting them". Overall, DEEWR is generally perceived as "unsupportive", "arrogant" and "inflexible". DEEWR's overriding interests in making the Job Network "work" as a quasi-market are clear to the case managers. For example:

DEEWR very rarely initiates policy or system changes which are beneficial to jobseekers or Job Network staff. They appear to be more concerned with saving money, creating as much paperwork as possible for Job Network providers.

DEEWR, it is believed, is too ready to place blame for system shortcomings on the Job Network members and to expect that system-level outcomes are the responsibility of that level only. Thus:

I believe that DEEWR has moved too far from the Job Network and there seems to be a poor relationship between DEEWR \& Job Network at the operational level. It is too easy for DEEWR to see short-comings as problems that are caused by the Job Network, rather than accept that the fundamental relationship between DEEWR, Job Network \& Centrelink is a serious fault in the overall operation of the System. 
I think DEEWR overrides outcomes in the most ridiculous situations. I feel there is too much pressure on Employment Consultants for more outcomes - staff morale is low and communication is stilted. Not only in my area of work - I have asked others in other Job Network providers and the same comments are said - too much work - not enough time - and negative points are highlighted with no positive feed back. Staff turn over is extremely high and people hate to come to work due to the pressure.

The following quote illustrates how the organisational rationality of public choice theory can be experienced as being in stark contrast to the human service focus of these organisations: "It's not unlike processing 'cattle' or should I say 'stock' which was the term DEEWR used at the start of the contract to describe their unemployed clients".

The relationship between DEEWR and individual organisations is described by some respondents in terms of intimidation. For example:

They need to start projecting a more accommodating and understanding image, instead of the culture of fear that they permeate through their contract managers, general staff, computer systems and general correspondence. The first thing we see each day on our computer when opening ea $3000^{4}$ is a message that threatens prosecution under the criminal code of conduct for providing misleading information.

In summary, despite theoretical requirement for mutual understanding, and for good relationships between contracting parties and within the overall quasi-market, it is clear that the Job Network is not characterised by trust. Rather, the purchaser - DEEWR - has taken the concerns about rent seeking behaviour to dysfunctional heights, resulting in low employee morale, high staff turnover, and significantly increased transaction costs in meeting compliance requirements. On the one hand, DEEWR distrusts providers in that they believe providers are seeking to maximise profits through short-changing the government. On the other, providers feel they are being micro-managed and over-regulated.

Below, we take a slightly different focus. Until now, we have examined the extent to which the Job Network exhibits features that, according to quasi-market theory, would make it effective. Now we take a deliberately normative stance and turn to the general principles of justice. We ask whether or not it is promoted in the Job Network quasi-market model of employment services. 


\section{Choice, Voice and Citizenship in the Job Network}

To be effective, social policy should - at a minimum - promote justice. Further, in a model which combines service delivery with activationinspired sanctions (withholding income security payments for noncompliance), justice becomes even more important.

First, the Job Network limits freedom of choice. Theoretically, the unemployed can "choose" a provider. In practice, most have a provider supplied to them by Centrelink. Also, under ESC 3, a person who is unhappy with that provider is not able to switch to another. In this way, a fundamental right to exit is barred, which means that the freedom of people to choose their provider is seriously constrained.

Second, and especially in the context of sanctions, unemployed people have limited access to remedy. If they are not satisfied with a provider, they may complain to that provider, and failing satisfactory resolution, to DEEWR. If that too fails, DEEWR claims that they may lodge a complaint with the Australian Ombudsman ${ }^{5}$ (Thomson 2007). However, there are doubts about this as a remedy in that private contractors do not fall within the jurisdiction of the Ombudsman (Livingston 2003; Owens 2001). This weak form of user rights is very different to the former public model wherein service users had full access to the administrative review system, including the Administrative Appeals Tribunal.

Unlike more traditional models of public service delivery, the Job Network, as a quasi-market, steps out of and makes redundant the regulatory framework provided by administrative law. As such, judicial and merits reviews are also unavailable in relation to decisions made by providers. Furthermore, private law remedies through contract law are inappropriate because the unemployed person is not a party to the contract. In addition, any reliance on tort law is, due to matters of cost, extremely unlikely to be a remedy of choice by an unemployed person. Consequently, the right to voice is compromised.

In the context of both exit and voice being effectively denied Job Network users, questions must be raised about whether the Job Network can be just. Further, the Job Network quasi-market unravels the relationship between citizen and the state to be found in more traditional models of state service delivery. This, in addition to the coercive nature of engagement driven by the sanctions regime, raises concerns about how unemployed people are conceptualised by the state via the prism of the Job Network. Put bluntly, the Job Network (and workfare policy more broadly) lumps the unemployed into a singular category of "citizenship", subject to conditions which do not apply to "normal" citizens. This cleavage through the citizenry has implications for the nature of Australian democracy.

Under the post-World War II settlement, the Australian citizen was constructed as a member of a unified, national and coherent political community whose interests were collectively expressed through 
institutionalised means within a stable system of governance. Those citizens' needs were met by the state through state agencies. A new form of service delivery has emerged which the Job Network exemplifies, representing an abrupt break with the past in terms both of the political settlement and of the model of citizenship. Unemployed citizens are now forced to be active consumers of marketised services, not clients of bureauprofessionals based in a state agency. It is a form of service delivery which fails in terms of elementary elements of justice. Irrespective of the particular political ideology driving the establishment of the Job Network, this situation is a function of the quasi-market.

\section{Conclusion}

While there is still little systematic knowledge about the effects of shifting to quasi-markets, we can conclude that, on its own terms, the implementation of the Job Network in Australia has failed to live up to expectations. As the market has matured, there are fewer providers and those that have survived are reluctant to take risks unless the outcomes are certain. Reregulation and bureaucratisation have increased both transaction costs and the administrative burden, leaving case managers at the front line with little time to focus on the needs of the job seeker. In turn, job seekers are given little information and are, more or less, placed with an agency on the basis of convenience and availability, not on the basis of quality. If things go wrong and the job seeker is dissatisfied, they have weak exit rights and limited access to independent appeal. In terms of the relationships between the purchaser and the providers, there is little evidence of trust and respect.

Returning to the question posed in the introduction to this discussion: Are the outcomes described here a function of the model (the quasi-market), or a function of this particular mode of application? In fairness, the answer is that it is probably a bit of both with a distinct lean to the peculiar version developed by DEEWR and the Australian government. The Job Network is an over-enthusiastic application of the quasi-market model which is heavily influenced by the politics of neo-liberalism. Because of that, the orientation of a punitive sanctions regime has reinforced the tendencies to distrustfulness embedded in public choice theory. It is a quasi-market that has, figuratively speaking, had a rush of blood to the head.

So, will there be any changes in the foreseeable future? Under the new Labor government elected in late 2007, there is unlikely to be any fundamental change to the model. The Employment Services Minister has indicated that the quasi-market design will stay, but that the sanctions regime will be softened. At the time of writing, the Australian government is seeking submissions on how the tendering process and the funding regime might be improved. The new government has also made a public commitment to make sure that the most disadvantaged do not fall between the cracks and that the Job Network focuses specifically on their needs. The unemployed will, for this reason at least, be better served. 


\section{Notes}

1. This Department has, over the ten years, had several names. This is its latest.

2. Centacare is a Catholic non-profit provider with approximately $7 \%$ of the Job Network business.

3. Department of Employment and Workplace Relations, a previous name for DEEWR.

4. Ea3000 is the information technology application and platform underpinning the Job Network.

5. See the following for guidelines for making a complaint: $h t t p: / / w w w . j o b a c c e s s$. gov.au/JOAC/Jobseekers/Help_available/Free_expert_help_with_employment/Job_Network/ Making_a_complaint.htm. Accessed 13 May, 2008.

\section{References}

Australian National Audit Office 2006, Implementation of Job Network Employment Services Contract 3, Audit Report No. 6, ANAO: Canberra, 2005-2006.

Bredgaard, T \& Larsen, F 2006, Quasi-Markets in Employment Services in Australia, the Netherlands and Denmark, Centre for Labour Market Research: Aalborg University, Denmark.

Buchanan, J M \& Tollison, R D 1972, Theory of Public Choice: Political Application of Economics, Ann Arbor: University of Michigan Press.

Buchanan, J M \& Tulloch, G 1962, The Calculus of Consent, Ann Arbor: University of Michigan Press.

Considine, M 2001, Enterprising States: The Public Management of Welfare to Work, Cambridge: Cambridge University Press.

Cowling, S \& Mitchell, W 2003, "False Promise or False? Evaluating the Job Network", Australian Journal of Labour Economics, 6 (2)

Davies, S 2008, "Contracting Out Employment Services to the Third and Private Sectors: A Critique”, Critical Social Policy, 28 (2).

Eardley, T 2003, "Non-Economic Perspectives on the Job Network", Australian Journal of Labour Economics, 6 (2)

Grossman, S J \& Hart, O D 1983, "An Analysis of the Principal-Agent Problem”, Econometrica, 51(1)

Hardy, B \& Wistow, G 1998, "Securing Quality Through Contracts? The Development of Quasi-Markets for Social Care in Britain", Australian Journal of Public Administration, 57 (2).

LeGrand, J \& Bartlett, W (eds), Quasi-Markets and Social Policy, London: Macmillan. 
Livingston, R 2003, "Contracting Out of Employment Services in Australia and Administrative Law", Australian Journal of Administrative Law, 10.

Lowery, D 1998, "Consumer Sovereignty and Quasi-Market Failure", Journal of Public Administration Research and Theory, 8 (2).

Murray, P 2006, A Job Network for Job Seekers: A Report on the Appropriateness of Current Services, Provider Incentives and Government Administration of Job Network, Catholic Social Services,

http://www.catholicsocialservices.org.au/system/files/CSSA_Job_Network_Discussions_Pap er_0.pdf Accessed 6 May 2008.

Nevile, J W \& Nevile, A 2003, "Evaluating the Structure and Performance of the Job Network", Australian Journal of Labour Economics, 6 (2).

Niskanen, W A 1971, Bureaucracy and Representative Government, Chicago: Aldine.

OECD 2001, Innovations in Labour Market Policies: The Australian Way. Paris: OECD.

Olson, M 1965, The Logic of Collective Action, Cambridge, Mass: Harvard University Press.

Owens, K 2001, 'The Job Network: How Legal and Accountable are its (Un)employment Services?", Australian Journal of Administrative Law, 8.

Productivity Commission 2002. Independent Review of the Job Network, Inquiry Report No 21, Canberra, 3 June.

Struyven, L 2004, Design Choices in Market Competition for Employment Services for the Long-term Unemployed, OECD Social, Employment and Migration Working Papers No 21, Paris: Employment, Labour and Social Affairs Committee.

Struyven, L \& Steurs, G 2005, “Design and Redesign of a Quasi-Market for the Reintegration of Job Seekers: Empirical Evidence from Australia and the Netherlands", Journal of European Social Policy, 15 (3).

Schwartz, H M 1994, "Public Choice Theory and Public Choice: Bureaucrats and State Reorganisation in Australia, Denmark, New Zealand and Sweden in the late 1980s", Administration and Society, 26 (1).

Thomas, M 2007, A Review of Developments in the Job Network, Research Paper No 15, Parliamentary Library, Department of Parliamentary Services, Parliament of Australia, Canberra.

Thompson, D 2008, Submission to The Hon Brendan O'Connor, Minister for Employment Participation, Jobs Australia Limited, Melbourne.

http://www.ja.com.au/home/article.aspx?id=12675 Accessed 6 May 2008.

Vanstone, A1996, Reforming Employment Assistance - Helping Australians into Real 
Jobs, Ministerial Statement by Senator the Honourable Amanda Vanstone, Minister for Employment, Education, Training and Youth Affairs.

Visser, J \& Hemerijck, A 1997, A Dutch Miracle: Job Growth, Welfare Reform and Corporatism in the Netherlands, Amsterdam: Amsterdam University Press.

Webster, M 1998, "Microeconomic Evaluations of Australian Labour Market Programs", Australian Economic Review, 32(2):

Williamson, O 1985, Economic Institutions of Capitalism, New York: Free Press.

Catherine McDonald is in the School of Global Studies, Social Science and Planning, RMIT University, Melbourne, and Greg Marston is in the School of Social Work and Applied Human Sciences, University of Queensland, Brisbane. 